\title{
Effect of Annealing Temperature on the Structural and Magnetic Properties of $\mathrm{NiFe}_{2} \mathrm{O}_{4}$ Nanoferrites
}

\author{
A. Sangeetha ${ }^{1 *}$, K. Vijaya Kumar ${ }^{2}$, G. Nanda Kumar ${ }^{3}$ \\ ${ }^{1}$ Department of Physics, Indur Institute of Engineering and Technology, Siddipet, India \\ ${ }^{2}$ Department of Physics, Jawaharlal Nehru Technological University, Hyderabad College of Engineering, Nachupally \\ (Kondagattu), Karimnagar-Dist., Telangana, India \\ ${ }^{3}$ Department of Geo-Physics, Osmania University, Hyderabad, India \\ Email: *sangeethaphd123@gmail.com
}

How to cite this paper: Sangeetha, A. Kumar, K.V. and Kumar, G.N. (2017) Effect of Annealing Temperature on the Structural and Magnetic Properties of $\mathrm{NiFe}_{2} \mathrm{O}_{4}$ Nanoferrites. Advances in Materials Physics and Chemistry, 7, 19-27.

https://doi.org/10.4236/ampc.2017.72003

Received: December 15, 2016

Accepted: February 6, 2017

Published: February 9, 2017

Copyright (C) 2017 by authors and Scientific Research Publishing Inc. This work is licensed under the Creative Commons Attribution International License (CC BY 4.0).

http://creativecommons.org/licenses/by/4.0/

\begin{abstract}
Nanocrystalline $\mathrm{NiFe}_{2} \mathrm{O}_{4}$ spinel ferrites were synthesized by sol-gel method. The structural and magnetic properties were investigated using X-ray diffraction (XRD), Fourier Transform Infrared (FTIR) spectroscopy, Scanning Electron Microscopy (SEM) and Vibrating Sample Magnetometer (VSM). Annealing temperature showed prominent effect on the grain size. The average grain size of $\mathrm{NiFe}_{2} \mathrm{O}_{4}$ was observed to increase from $31 \mathrm{~nm}$ to $54 \mathrm{~nm}$ as the annealing increased from $500^{\circ} \mathrm{C}$ to $1000^{\circ} \mathrm{C}$. The IR spectra showed the absorption bands corresponding to stretching of tetrahedral and octahedral bands. The magnetic properties were observed to depend strongly on the annealing temperature.
\end{abstract}

\section{Keywords}

Sol-Gel, Nickel Ferrite, Crystallite Size, Structural Properties, Magnetic Properties

\section{Introduction}

Nickel ferrite $\left(\mathrm{NiFe}_{2} \mathrm{O}_{4}\right)$ is an important member of the spinel family and it is found to be the most versatile technological material suited for high-frequency applications due to its high resistivity [1] [2]. In the bulk state, this material possesses an inverse spinel structure, in which tetrahedral (A) sites are occupied by $\mathrm{Fe}^{3+}$ ions and octahedral (B) sites by $\mathrm{Fe}^{3+}$ and $\mathrm{Ni}^{2+}$ ions. It is found from literature that ferromagnetism in $\mathrm{NiFe}_{2} \mathrm{O}_{4}$ originates from the antiparallel orientation of spins at (A) and (B) sites. Recently graphene oxide based inverse spinel nickel 
ferrite nanocomposite was used for uranium, thorium and dipyrone removal [3] [4]. Nickel ferrite nanoparticles in calcium phosphate nanostructure for organic modifier followed by rapid thermal processing in biomedical applications [5], rare earth doped nickel ferrites as fuel [6], Ni ferrite powders are prepared by plasma arc discharge process [7].

Previously several researchers have worked on $\mathrm{NiFe}_{2} \mathrm{O}_{4}$ materials in bulk, nano and thin film form and they presented interesting results. Unexpected magnetism in some ferrites has been observed due to homogenous mixing [8], without post annealing [9] or with annealing [10]. However, there are only few articles which explain the effect of annealing temperature on ferrite nanomaterials and especially on Nickel ferrites. Therefore, in this present work, we are reporting in detail the structural and magnetic properties of $\mathrm{NiFe}_{2} \mathrm{O}_{4}$ nanoparticles due to effect of annealing temperature. The $\mathrm{NiFe}_{2} \mathrm{O}_{4}$ nanoferrites were characterized by using X-ray diffraction (XRD), Fourier Transform Infrared (FTIR) and Scanning Electron Microscopy (SEM) and the magnetic properties were investigated using Vibrating Sample Magnetometer (VSM) with an applied of $10 \mathrm{kOe}$ at room temperature.

\section{Experimental Procedure}

$\mathrm{NiFe}_{2} \mathrm{O}_{4}$ nanoferrites were prepared by using sol-gel method [11]. The a.r. grade citric acid $\left(\mathrm{C}_{6} \mathrm{H}_{8} \mathrm{O}_{7} \cdot \mathrm{H}_{2} \mathrm{O}\right)$, nickel nitrate $\left(\mathrm{Ni}\left(\mathrm{NO}_{3}\right)_{2} \cdot 6 \mathrm{H}_{2} \mathrm{O}\right)$, ferric nitrate $\left(\mathrm{Fe}\left(\mathrm{NO}_{3}\right)_{3} \cdot 9 \mathrm{H}_{2} \mathrm{O}\right)$ from SD fine chemicals were used as starting materials. The synthesis technique is described in detail elsewhere [11]. The obtained raw powders were annealed separately at different temperatures ranging from $500^{\circ} \mathrm{C}$, $600^{\circ} \mathrm{C}, 700^{\circ} \mathrm{C}, 800^{\circ} \mathrm{C}, 900^{\circ} \mathrm{C}$ and $1000^{\circ} \mathrm{C}$ for 5 hours.

XRD analysis was measured using Philips PW 3020 Bragg-Brentano dif-fractometer using $\mathrm{Cu} \mathrm{K} \alpha$ radiation (wave length $\lambda=1.54 \AA$ ). The morphology of powder was observed using scanning electron microscopy (SEM) from Carl Zeiss. The structural changes were observed using ABB Bomem MB 102 infrared spectrometer. The samples were mixed with $\mathrm{KBr}$ and made in the form of pellets and recorded at $4 \mathrm{~cm}^{-1}$ resolution giving the spectra in the $4000-200 \mathrm{~cm}^{-1}$ range. Room temperature magnetization was measured using $\mathrm{ADE}$ magnetics DMS 4 Vibrating Sample Magnetometer (VSM) Ltd.

\section{Results and Discussions}

Figure 1 shows the $\mathrm{XRD}$ patterns of $\mathrm{NiFeO}_{4}$ nanoferrite samples annealed from $500^{\circ} \mathrm{C}, 600^{\circ} \mathrm{C}, 700^{\circ} \mathrm{C}, 800^{\circ} \mathrm{C}, 900^{\circ} \mathrm{C}$ and $1000^{\circ} \mathrm{C}$ for 5 hours. The XRD peaks correspond to the formation of $\mathrm{NiFeO}_{4}$ ferrite structure. A close examination of XRD peaks reveals that the peaks became narrower and sharper. This might be due to the increase in the grain size. The crystallite sizes for all the samples were measured by considering the most intense (311) peak of XRD using the DebyeScherrer Formula (1).

$$
D=\frac{0.9 \lambda}{\beta \cos \theta}
$$




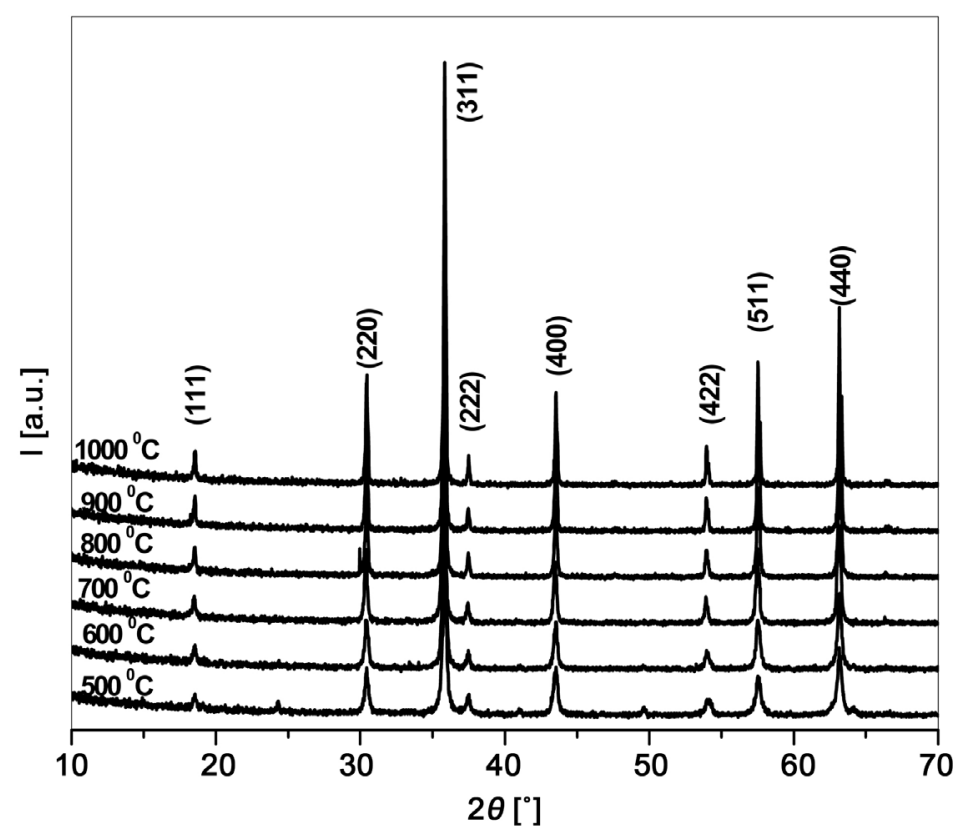

Figure 1. XRD patterns of $\mathrm{NiFe}_{2} \mathrm{O}_{4}$ nanoferrites annealed at different temperatures.

where, $D$ is the crystallite size, $\lambda$ is the wavelength, $\beta$ is the full width at half maxima (FWHM) and $\theta$ is the Bragg's angle.

With the increase in the annealing temperature from $500^{\circ} \mathrm{C}$ to $1000^{\circ} \mathrm{C}$, the grain size was observed to increase from 31 to $54 \mathrm{~nm}$ as shown in Table 1.

The annealing temperature showed the significant effect on the $\mathrm{NiFe}_{2} \mathrm{O}_{4}$ grain size. This might be directly related to the crystallization of the nanoparticles. A straight line of $\ln (d)$ against $1 / T$ (Figure 2) is plotted according with the Scott Equation (1) under the homogeneous growth rate conditions of nanocrystallites [12] [13]. The Scott equation describes the growth rate of nanocrystallites as a result of thermal treatment of amorphous compounds.

$$
d=C \exp (-E / R T)
$$

where, $d$ is the grain size calculated from XRD, $C$ is a constant, $E$ is the activation energy for grain growth, $R$ is the ideal gas constant and $T$ is the absolute temperature.

There exists a good linear relationship between $\ln d$ and $1 / T$. $E$ values could be calculated from the slope of the straight line, presented in Figure 2. As $E=11.4$ $\mathrm{kJ} / \mathrm{mol}$, it can be considered that the grain grows primarily due to the interfacial reaction. Therefore, it can be confirmed that $\mathrm{NiFe}_{2} \mathrm{O}_{4}$ nano crystals are easily affected with the annealing temperature as shown in Figure 2. In our $\mathrm{NiFe}_{2} \mathrm{O}_{4}$ samples, we observed the activation energy of $11.4 \mathrm{~kJ} / \mathrm{mol}$ compared with 18.5 $\mathrm{kJ} / \mathrm{mol}$ for ball milled $\mathrm{NiFe}_{2} \mathrm{O}_{4}$ samples [13].

The IR spectra of $\mathrm{NiFe}_{2} \mathrm{O}_{4}$ nanoparticles annealed at different temperatures are presented in Figure 3. $\mathrm{NiFe}_{2} \mathrm{O}_{4}$ gives rise to two main absorption bands, consisting of metal-oxygen stretching bands $v_{1}$ and $v_{2}$, in the range $600-540$ $\mathrm{cm}^{-1}$ and $400-380 \mathrm{~cm}^{-1}$, respectively. Considering the inverse spinel structure of 
Table 1. Dependence of grain size $D$, saturation magnetization $M_{\mathrm{S}}$ and coercive field $H_{\mathrm{C}}$ on different temperatures.

\begin{tabular}{cccc}
\hline Temperature ${ }^{\circ} \mathrm{C}$ & $D(\mathrm{~nm})$ & $M_{\mathrm{s}}(\mathrm{emu} / \mathrm{g})$ & $H_{\mathrm{C}}(\mathrm{Oe})$ \\
\hline 500 & 31 & 29.7 & 199 \\
600 & 35 & 31.8 & 151 \\
700 & 42 & 35.9 & 129 \\
800 & 46 & 40.9 & 121 \\
900 & 49 & 44.2 & 69 \\
1000 & 54 & 34.9 & 54 \\
\hline
\end{tabular}

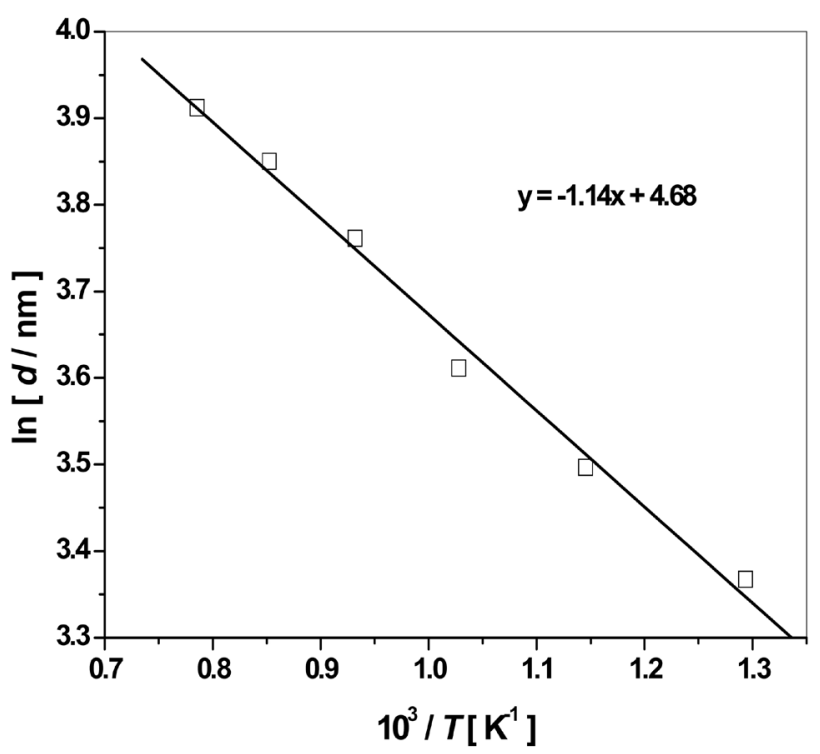

Figure 2. Plot of $\ln (d)$ against $1 / T$. Line presents a linear fit for $\ln (d)$ vs. $1 / T$ dependence.

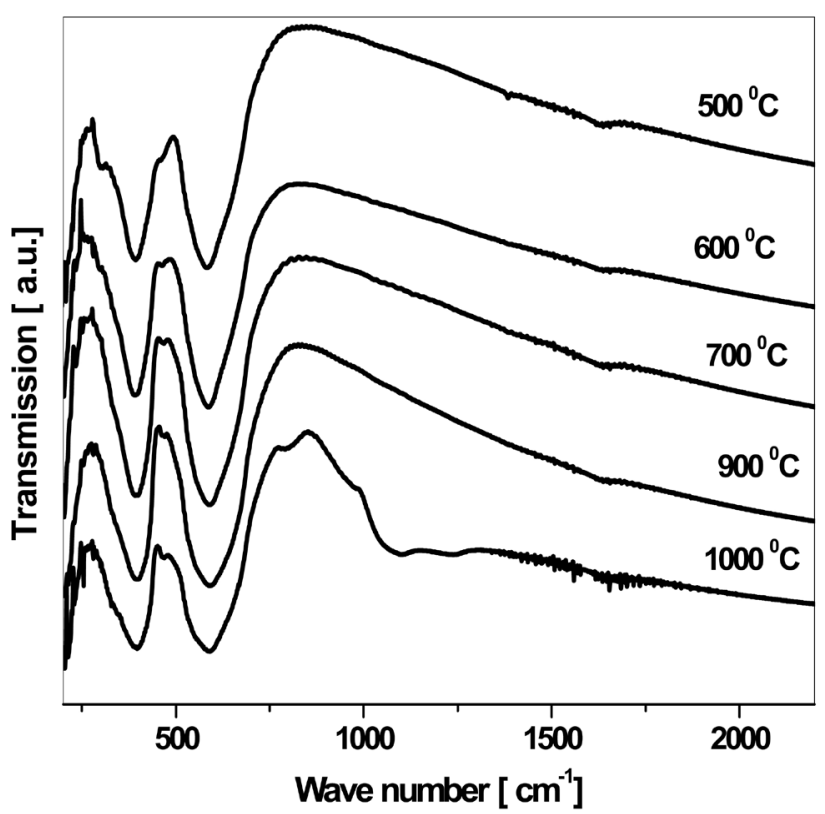

Figure 3. IR spectra of $\mathrm{NiFe}_{2} \mathrm{O}_{4}$ nanoferrites annealed at different temperatures. 
the $\mathrm{NiFe}_{2} \mathrm{O}_{4}$ it is represented by general formula $\mathrm{Fe}^{3+}\left[\mathrm{Ni}^{2+} \mathrm{Fe}^{3+}\right] \mathrm{O}_{4}$, where square brackets represents the octahedral sites [14], $V_{1}$ band corresponds to intrinsic stretching vibrations of tetrahedral $\mathrm{Fe}^{3+}-\mathrm{O}$, while $v_{2}$ is assigned to $\mathrm{Fe}^{3+}-\mathrm{O}$ and $\mathrm{Ni}^{2+}$-O bond stretching vibrations of octahedral sites [15]. Therefore, IR analysis clearly showed the formation of the inverse spinel structure of $\mathrm{NiFe}_{2} \mathrm{O}_{4}$ and the band positions were observed to shift their positions with the increase in annealing temperature from $500^{\circ} \mathrm{C}$ to $1000^{\circ} \mathrm{C}$.

Figure 4 shows the SEM micrographs of $\mathrm{NiFe}_{2} \mathrm{O}_{4}$ samples annealed at $500^{\circ} \mathrm{C}$, $800^{\circ} \mathrm{C}, 900^{\circ} \mathrm{C}$ and $1000^{\circ} \mathrm{C}$. The SEM micrographs show a slight agglomeration among the particles. These nanoparticles distinctly exhibit narrow particle size distribution. SEM image of the sample fired at $500^{\circ} \mathrm{C}$, Figure 4 (a) shows that the microstructure has fairly small grain size. As the annealing temperature was increased to $800^{\circ} \mathrm{C}$ and $900^{\circ} \mathrm{C}$, Figure 4 (b) to Figure 4 (c) a clear crystal structure having homogeneous microstructure with uniform size distribution. With the further increase of annealing temperature up to $1000^{\circ} \mathrm{C}$, Figure $4(\mathrm{~d})$ a nonuniform grain growth with the presence of intragranular pores was observed. It was observed in other ferrite samples that the sample fired at $1300^{\circ} \mathrm{C}$ showed abnormal grain growth and closed pores [16]. Suck kind of pores may be accounted for the poor physico-mechanical properties and decrease in magnetization. In the present case, the samples fired at $1000^{\circ} \mathrm{C}$ (Figure 4 (d)) did not show any abnormal grain growth and very small amount of pores were observed in comparison with other ferrite materials [17].
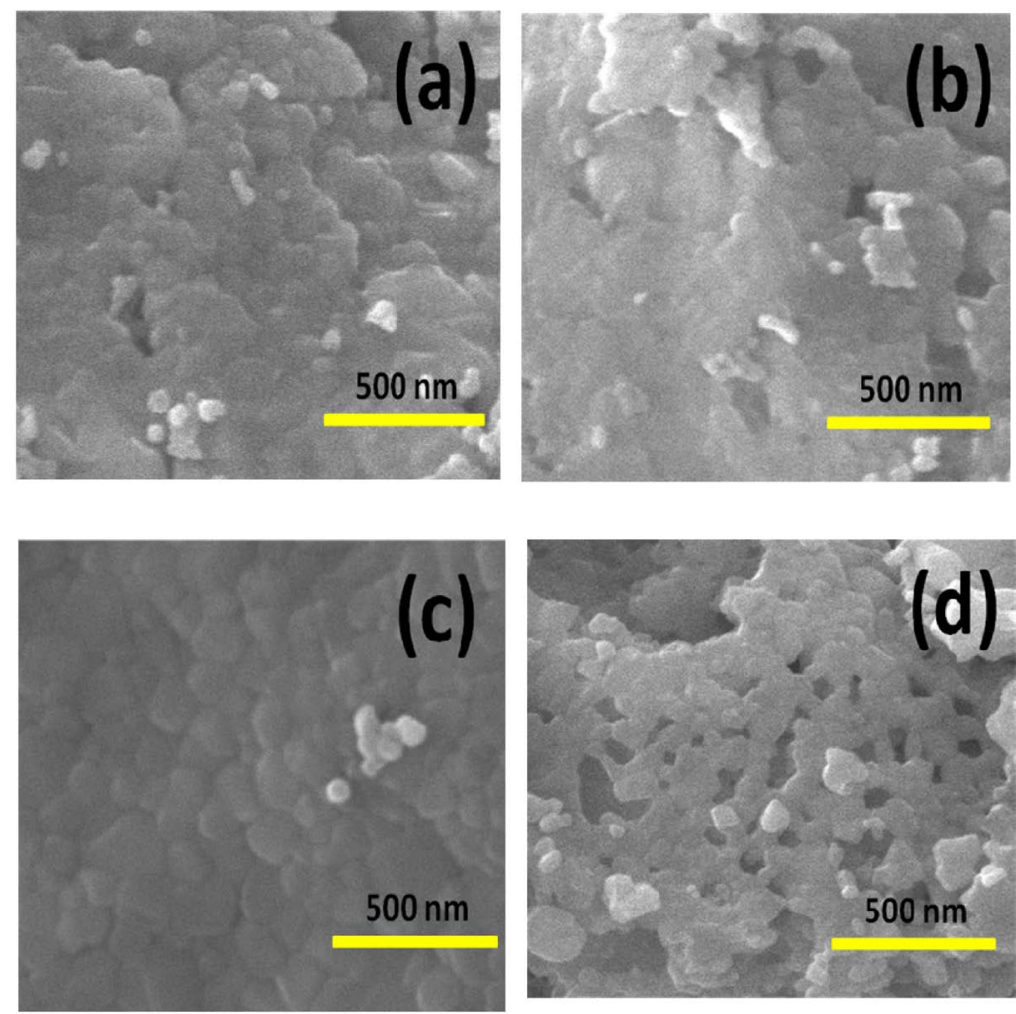

Figure 4. $\mathrm{SEM}$ micrographs of $\mathrm{NiFe}_{2} \mathrm{O}_{4}$ nanoferrites annealed at temperatures (a) $500^{\circ} \mathrm{C}$, (b) $800^{\circ} \mathrm{C}$, (c) $900^{\circ} \mathrm{C}$ and (d) $1000^{\circ} \mathrm{C}$. 
The room-temperature magnetization measurements for all the annealed $\mathrm{NiFe}_{2} \mathrm{O}_{4}$ samples from $500^{\circ} \mathrm{C}$ to $1000^{\circ} \mathrm{C}$ are shown in Figure 5. The derived parameters are shown in Table 1 . The saturation maximum magnetization for $500^{\circ} \mathrm{C}$ annealed sample was found to be $29.7 \mathrm{emu} / \mathrm{g}$, which is about $40 \%$ smaller than the saturation magnetization of $50 \mathrm{emu} / \mathrm{g}$ of bulk $\mathrm{NiFe}_{2} \mathrm{O}_{4}$ samples [17]. As the annealing temperature was increased to $900^{\circ} \mathrm{C}$, the saturation magnetization was observed to be $44.2 \mathrm{emu} / \mathrm{g}$, which is equal to the saturation magnetization of bulk $\mathrm{NiFe}_{2} \mathrm{O}_{4}$ ferrite samples [13].

It is clearly observed that the saturation magnetization increased with increase in the annealing temperature and grain size. Similar kind of magnetization behavior was observed for different ferrite systems. In addition, the reduced magnetization in nanomaterials also leads to the reduced ordering temperature and increased anisotropy [18]. Therefore, the reduced magnetization in nanoferrites is often connected to the existence of a "magnetically dead" layer at the surface of particles explained in terms of core-shell exchange-coupling [19], where a ferrimagnetic core is surrounded by a surface layer of canted spins. However, in the case of some nanoferrites the core-shell model failed to explain the enhancement of magnetization [20] [21] [22]. It is observed that the reduction of magnetic moment is observed only in the case when the effect of spin canting in the shell dominates over the effect of cation disorder; otherwise an unusual phenomenon like the magnetization enhancement may be expected [23]. The reduced magnetization with the decreasing particle size observed in the present case can be attributed to the prevailing effect of spin non-collinearity in the near-surface layers of the $\mathrm{NiFe}_{2} \mathrm{O}_{4}$ crystals. It is noted that the decrease in the magnetization in the case of the sample annealed at $1000^{\circ} \mathrm{C}$ may be due to the excessive temperature which quickens the ion diffusion during annealing and the formation of pores. As a consequence, the domain wall movement becomes difficult, which causes

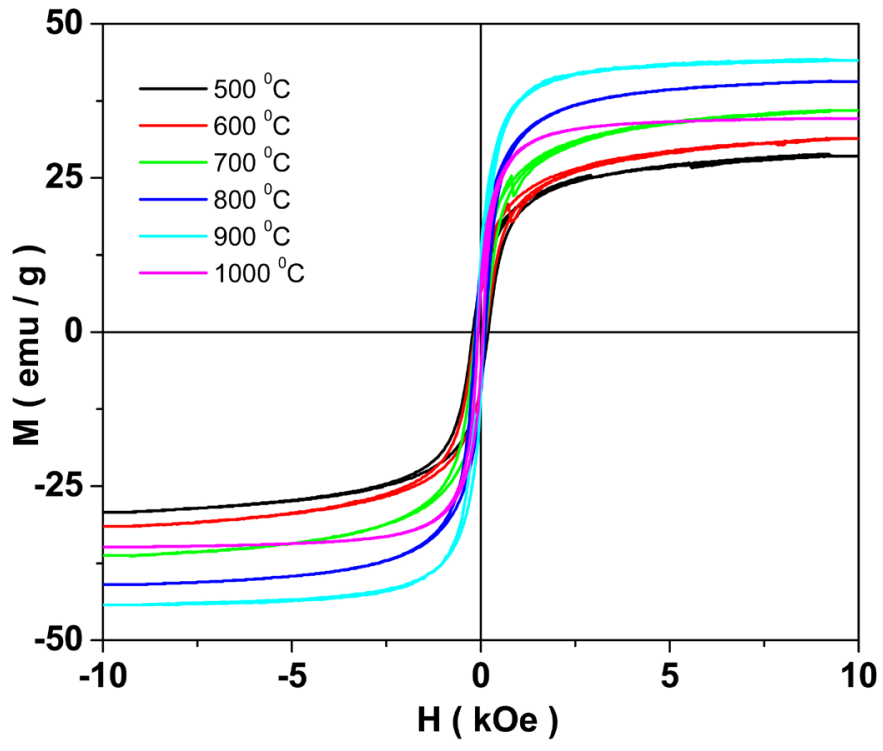

Figure 5. Hysteresis loops for $\mathrm{NiFe}_{2} \mathrm{O}_{4}$ nanoferrites annealed at different temperatures. 


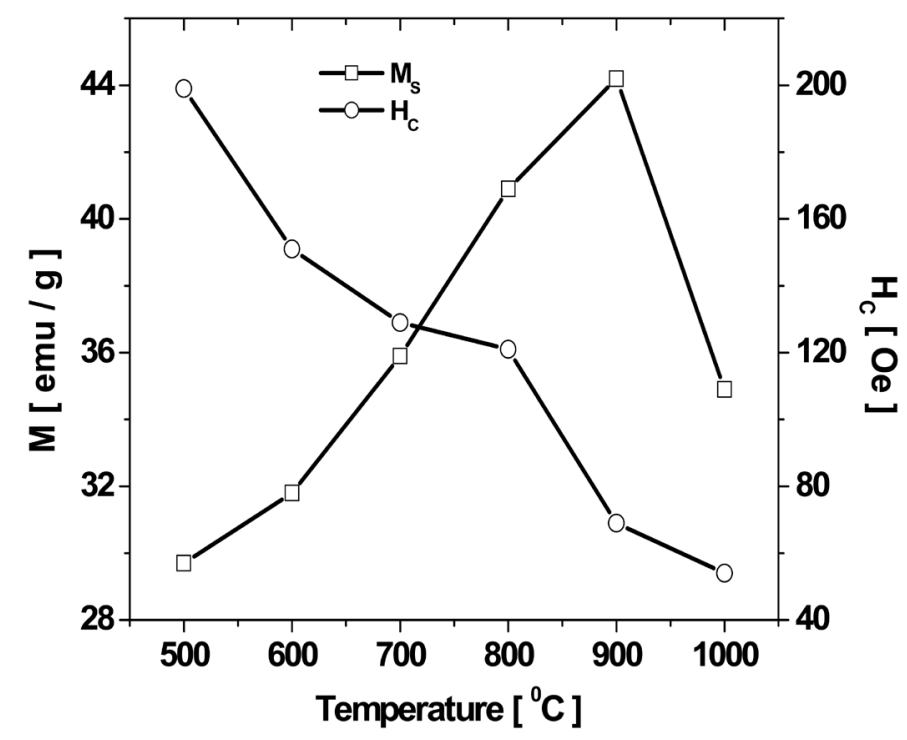

Figure 6. Variation of magnetization in $10 \mathrm{kOe}$ and coercive field for $\mathrm{NiFe}_{2} \mathrm{O}_{4}$ nanoferrites annealed at different temperatures.

the magnetization to decrease. A similar change in magnetization with the annealing temperature was observed for $\mathrm{CuFe}_{2} \mathrm{O}_{4}$ nanoparticles [16]. Further, due to the formation of pores higher annealed samples has resulted in the decrease of magnetization.

The coercivity was observed to decrease with increasing annealing temperature as shown in Figure 6. The coercivity in the case of $500^{\circ} \mathrm{C}$ annealed sample is nearly three times more than that of the bulk $\mathrm{NiFe}_{2} \mathrm{O}_{4}$ [24]. With the increase in annealing temperature the coercivity gradually decreased and attained a minimum value of $7.2 \mathrm{Oe}$. The decrease in the coercivity with annealing temperature may also be accounted for the multi domain nature in the samples at higher annealing temperatures [25].

\section{Conclusion}

$\mathrm{NiFe}_{2} \mathrm{O}_{4}$ nanoferrites were successfully synthesized using sol-gel method. The grain size was observed to increase with increasing annealing temperature. The activation energy was observed to be $11.4 \mathrm{~kJ} / \mathrm{mol}$. The annealing temperature showed significant effect on the grain growth. The IR analysis confirmed the ferrite phase formation by showing the bands corresponding to the tetrahedral and octahedral sites. The saturation magnetization was observed to increase with increase of grain size as a consequence of annealing temperature. Pores were observed to form with higher annealing temperature of $1000^{\circ} \mathrm{C}$ due to which magnetization decreased. The coercivity decreased with increasing annealing temperature.

\section{References}

[1] Goldman, A. (2006) Modern Ferrite Technology. 2nd Edition, Springer, New York.

[2] Snelling, E.C. (1983) Ferrites for Inductors and Transformers. Research Studies 
Press, Letchworth, New York.

[3] Lingamdinne, L.P., Choia, Y.L., Kimb, I.M., Yangc, J.K., Janardhan, R.K. and Chang, Y.Y. (2017) Preparation and Characterization of Porous Reduced Graphene Oxide Based Inverse Spinel Nickel Ferrite Nanocomposite for Adsorption Removal of Radionuclides. Journal of Hazardous Materials, 326, 145-156. https://doi.org/10.1016/j.jhazmat.2016.12.035

[4] Springer, V., Pecini, E. and Avena, M. (2016) Magnetic Nickel Ferrite Nanoparticles for Removal of Dipyrone from Aqueous Solutions. Journal of Environmental Chemical Engineering, 4, 3882-3890. https://doi.org/10.1016/j.jece.2016.08.026

[5] Ruthradevi, T., Akbar, J., Suresh Kumar, G., Thamizhavel, A., Kumar, G.A., Vatsa, R.K., Dannangoda, G.C., Martirosyan, K.S. and Girija, E.K. (2017) Investigations on Nickel Ferrite Embedded Calcium Phosphate Nanoparticles for Biomedical Applications. Journal of Alloys and Compounds, 695, 3211-3219.

https://doi.org/10.1016/j.jallcom.2016.11.300

[6] Samoilaa, P., Cojocarua, C., Sacarescu, L., Dorneanu, P.P., Domocos, A.A. and Rotaru, A. (2017) Remarkable Catalytic Properties of Rare-Earth Doped Nickel Ferrites Synthesized by Sol-Gel Auto-Combustion with Maleic Acid as Fuel for CWPO of Dyes. Applied Catalysis B: Environmental, 202, 21-32. https://doi.org/10.1016/j.apcatb.2016.09.012

[7] Safari, A., Gheisari, K.H. and Farbod, M. (2017) Characterization of Ni Ferrites Powders Prepared by Plasma Arc Discharge Process. Journal of Magnetism and Magnetic Materials, 421, 44-51. https://doi.org/10.1016/j.jmmm.2016.07.024

[8] Saidani, M., Belkacem, W., Bardeau, J.F., Bezergheanu, A., Patout, L. and Mlikia, N. (2017) Unexpected Magnetic Properties Explained by the Homogeneity of Mixed Ferrites. Journal of Alloys and Compounds, 695, 183-193.

https://doi.org/10.1016/j.jallcom.2016.10.091

[9] Safi, R., Ghasemi, A. and Shoja-Razavi, R. (2016) A Novel Approach for Enhancement of Coercivity in Magnetic Cobalt Ferrite Nanocrystal without Applying Post Annealing. Ceramics International, 42, 17357-17365.

https://doi.org/10.1016/j.ceramint.2016.08.033

[10] Amer, M.A., Meaz, T.M., Mosrafa, A.G. and El-Ghazally, H.F. (2015) Annealing Effect on the Structural and Magnetic Properties of the $\mathrm{CuAl}_{0.6} \mathrm{Cr}_{0.2} \mathrm{Fe}_{1.2} \mathrm{O}_{4}$ Nano-Ferrites. Materials Research Bulletin, 67, 207-214. https://doi.org/10.1016/j.materresbull.2015.03.031

[11] Vijaya Kumar, K., Sangeetha, A., Raghavender, A.T., Skoko, Z. and Nanda Kumar, G. (2012) Rietveld Refinement of Nanocrystalline $\mathrm{LiFeO}_{2}$ Synthesized by Sol-Gel Method and Its Structural and Magnetic Properties. Journal of Crystallization Process and Technology, 2, 152-155. https://doi.org/10.4236/jcpt.2012.24022

[12] Scott, M.G. (1983) Amorphous Metallic Alloys. Butterworths, London, 151.

[13] Yang, H., Zhang, X., Huang, C., Yang, W. and Qiu, G. (2004) Synthesis of $\mathrm{ZnFe}_{2} \mathrm{O}_{4}$ Nanocrystallites by Mechanochemical Reaction. Journal of Physics and Chemistry of Solids, 65, 1329-1332. https://doi.org/10.1016/j.jpcs.2004.03.001

[14] Cotton, F.A. and Wilkinson, G. (1988) Advanced Inorganic Chemistry. 5th Edition, John Willey and Sons, New York, 9.

[15] Waldron, R.D. (1955) Infrared Spectra of Ferrites. Physical Review, 99, 1727-1735. https://doi.org/10.1103/PhysRev.99.1727

[16] Ahmed, Y.M.Z., Hessien, M.M., Rashad, M.M. and Ibrahim, I.A. (2009) Nano Crystalline Copper Ferrites from Secondary Iron Oxide (Mill Scale). Journal of Magnetism and Magnetic Materials, 321, 181-187. 
https://doi.org/10.1016/j.jmmm.2008.08.100

[17] Maensiri, S., Masingboon, C., Boonchom, B. and Seraphin, S. (2007) A Simple Route to Synthesize Nickel Ferrite $\left(\mathrm{NiFe}_{2} \mathrm{O}_{4}\right)$ Nanoparticles Using Egg White. Scripta Materialia, 56, 797-800. https://doi.org/10.1016/j.scriptamat.2006.09.033

[18] Sepelak, V., Baabe, D., Mienert, D., Schultze, D., Krumeich, F., Litterst, F.J. and Becker, K.D. (2003) Evolution of Structure and Magnetic Properties with Annealing Temperature in Nanoscale High-Energy-Milled Nickel Ferrite. Journal of Magnetism and Magnetic Materials, 257, 377-386. https://doi.org/10.1016/S0304-8853(02)01279-9

[19] Kodama, R.H. and Berkowitz, A.E. (1999) Atomic-Scale Magnetic Modeling of Oxide Nanoparticles. Physical Review B, 59, 6321-6336.

https://doi.org/10.1103/PhysRevB.59.6321

[20] Bhowmik, R.N., Ranganathan, R., Nagarajan, R., Ghosh, B. and Kumar, S. (2005) Role of Strain-Induced Anisotropy on Magnetic Enhancement in Mechanically Alloyed $\mathrm{Co}_{0.2} \mathrm{Zn}_{0.8} \mathrm{Fe}_{2} \mathrm{O}_{4}$ Nanoparticle. Physical Review B, 72, Article ID: 094405. https://doi.org/10.1103/PhysRevB.72.094405

[21] Gholizadeh, A. and Jafari, E. (2017) Effects of Sintering Atmosphere and Temperature on Structural and Magnetic Properties of Ni-Cu-Zn Ferrite Nano-Particles: Magnetic Enhancement by a Reducing Atmosphere. Journal of Magnetism and Magnetic Materials, 422, 328-336. https://doi.org/10.1016/j.jmmm.2016.09.029

[22] Franco Jr., A., Pereira Alves, T.E., De Oliveira Lima, E.C., Da Silva Nunes, E. and Zapf, V. (2009) Enhanced Magnetization of Nanoparticles of $\mathrm{Mg}_{x} \mathrm{Fe}_{(3-x)} \mathrm{O}_{4}(0.5 \leq x \leq 1.5)$ Synthesized by Combustion Reaction. Applied Physics A, 94, 131-137. https://doi.org/10.1007/s00339-008-4684-y

[23] Sepelak, V., Bergmann, I., Menzel, D., Feldhoff, A., Heitjans, P., Litterst, F.J. and Becer, K.D. (2007) Magnetization Enhancement in Nanosized $\mathrm{MgFe}_{2} \mathrm{O}_{4}$ Prepared by Mechanosynthesis. Journal of Magnetism and Magnetic Materials, 316, e764-e767. https://doi.org/10.1016/j.jmmm.2007.03.087

[24] Huang, X. and Chen, Z. (2004) Nickel Ferrite on Silica Nanocomposites Prepared by the Sol-Gel Method. Journal of Magnetism and Magnetic Materials, 280, 37-43. https://doi.org/10.1016/j.jmmm.2004.02.020

[25] George, M., Nair, S.S., John, A.M., Joy, P.A. and Anantharamam, M.R. (2006) Structural, Magnetic and Electrical Properties of the Sol-Gel Prepared $\mathrm{Li}_{0.5} \mathrm{Fe}_{2.5} \mathrm{O}_{4}$ Fine Particles. Journal of Physics D: Applied Physics, 39, 900-910. https://doi.org/10.1088/0022-3727/39/5/002 
Submit or recommend next manuscript to SCIRP and we will provide best service for you:

Accepting pre-submission inquiries through Email, Facebook, LinkedIn, Twitter, etc. A wide selection of journals (inclusive of 9 subjects, more than 200 journals)

Providing 24-hour high-quality service

User-friendly online submission system

Fair and swift peer-review system

Efficient typesetting and proofreading procedure

Display of the result of downloads and visits, as well as the number of cited articles Maximum dissemination of your research work

Submit your manuscript at: http://papersubmission.scirp.org/

Or contact ampc@scirp.org 